\title{
About relict larches of mountain forest steppe of South Siberia
}

\author{
Bimba Namzalov $^{1 *}$, and Nikolay Dubrovsky ${ }^{2}$ \\ ${ }^{1}$ State Scientific Institution "Buryat Research Institute of Agriculture”, 670045, Tretiakova str. 25z, \\ Ulan-Ude, Russia \\ ${ }^{2}$ Tuva State University, 667000, Lenin str. 36, Kyzyl, Russia
}

\begin{abstract}
The paper provides original information about relict phenomena in the structure of the forest component of the mountain forest-steppe of Southern Siberia (SS). Larch (Larix sibirica Ledeb.) shrub-grass forests are a characteristic element of vegetation in the forest-steppe of the SS. The oldest are the Pliocene, the most thermophilic analogues of the modern forest-steppe, noted in the foothills of the Western Tannu-Ola ridge (natural boundary Khorlety) - is a small-leaved honeysuckle-wormwood larch forest with participation in the community of highland-Asian elements of ancient Middle-earth - Lonicera microphylla, Cotoneaster megalocarpus, Spiraea hypericifolia. In the conditions of Western Transbaikalia, in the spurs of the Malyi Khamar-Daban ridge (natural boundary Inzagatuy) described the relict sedge-needlegrass larch forest with the participation of characteristic species of the periglacial Pleistocene complex such as Helictotrichon altaicum, Festuca sibirica, Artemisia commutata and others. In the Quaternary period - especially in the xerothermic phases of the Holocene, as mountain glaciers were deglaciated and a relatively warm and temperate climate develops, conditions are created for the formation of a modern mountain forest-steppe in the conditions of the semi-humid climatic regime of the SS.
\end{abstract}

In accordance with the modern concept of biodiversity, the concept of "relict" must be considered broadly, highlighting relict phytosystems not only of the species, but also of the coenotic and landscape level [1]. At the same time, the last two deserve special attention, since there are few revealed relict communities and especially landscapes discovered by geobotanists. The communities of nemoral limestones, or the "linden island" of Altai and the relict landscape of the tundra-steppe in the dry highlands of Tuva and southeastern Altai are classic [2]. It should be noted that the concept of "relict" at the community level has its own characteristics. In terms of methodology, the identification of those structural elements of plant communities that determine their relict nature becomes most important. As such, it is not only the relict species - the dominant or the identifier of the community, but also the combinations of relict species-associators and their coenopopulations within individual tiers, parcels and synusias of the plant community.

\footnotetext{
* Corresponding author: namzalov@rambler.ru
} 
Larch (Larix sibirica Ledeb.) shrub-grass forests are a characteristic element of the belt of the mountain forest-steppe of Southern Siberia (SS). As you know, one of the newest centers for the formation of the genus Larix L. is Northeast Asia; within it, at the initial stages of the Cenozoic in the Paleogene-Neogene, later - in the era of the Pleistocene glaciations, siberian larch was formed [3]. In the structure of the mountain forest-steppe community of grass larch have a number of features, confirming their relict. This work is devoted to the consideration of precisely this phenomenon in the landscapes of the foreststeppe of the SS in a historical retrospective.

In the course of our many years of research [4] of the vegetation of the forest-steppe belt in the mountains of the SS, from Altai to the Selenga Dauria in Transbaikalia, we described the original larch communities in the mountain forest-steppe, which, according to our ideas, indicate different manifestations of relictness in the structure of the forest-steppe landscape. Next, we consider the features of their species composition and intracenotic organization (Fig. 1, 2). They formed under conditions of thermally favorable and sufficient moisture, had a savannoid appearance. The intra-landscape differentiation of vegetation followed the path of the development of multidominant shrub thickets in the meso-hollow and on more humid expositions of the slopes. Moreover, in these complexes composed of various shrubs and herbaceous plants, the participation of woody forms was fragmentary. Light coniferous and deciduous species (species from the genera Pinus, Larix, Ulmus, Betula) were composed this component. However, the role of boreal species in the structure of coenoses was insignificant in comparison with the thermophilic highland-Asian elements. Especially significant was their role in the shrub layer of forest communities. In general, the formation of forests of the ancient forest-steppe, apparently, occurred as a result of invasion of woody plants in petrolithogenic groups of the ancient Mediterranean semiarid types - shrub, shrubgrass [5].

As a result of the incumbation-decumbation of the tree layer, in the shrubbery groups forest communities of the ancient forest-steppe were formed [6]. Such phylocenogenetic processes during the formation of relict complexes in vegetation are noted by V. B. Sochava [6] - "Communities, tiers and sinusia within the type of vegetation are closely related to each other. This relationship is manifested in the change in time (spontaneously and under the influence of a person) of one type of community to another (forest - shrub, meadow-bog, etc.), in the phenomena of incumbation and decumbation of tiers, the adjacent development of sinusias, in the development of the same or very similar synusias in structure in various associations and formations, in the presence of predominant species specific for vegetation type and in other similar manifestations "(p. 12). We noted a modern analogue of relict larch in the Khorleta valley in the foothills of the southern macro slope of the Western Tannu-Ola ridge (Fig. 1.2). This is a honeysuckle-wormwood larch, the community was described on the slope of the northeastern exposition of a rocky ridge. In the course of field studies, we were able to identify the stages of coenogenesis of relict larch, which are certain stages in the development of the community in the structure of the forest-steppe complex. The formation of the relict coenocomplex Lariceta sibirica (from primary groups to developed cenosis) begins with the process of invasion-ecessis of larch diasporas into the community of relict shrub petrophyton - thickets of xeromorphic deciduous shrubs ("Tuvinian shiblyak"), composed with the combination of highland-Asian elements of ancient Middle-earth. 


\begin{tabular}{|c|c|c|c|}
\hline $\begin{array}{c}\text { Cenozoic } \\
\text { (time stages) }\end{array}$ & $\begin{array}{c}\text { Pliocene } \\
3.5 \text { - 8 million years }\end{array}$ & $\begin{array}{c}\text { Pleistocene } \\
250 \text { - } 120 \text { to } 50 \\
\text { thousand years }\end{array}$ & $\begin{array}{c}\text { Holocene } \\
\text { (xerothermic } \\
\text { phases) }\end{array}$ \\
\hline $\begin{array}{l}\text { Geographical } \\
\text { position }\end{array}$ & $\begin{array}{l}\text { Tuva. Western Tannu- } \\
\text { Ola ridge }\end{array}$ & $\begin{array}{c}\text { Transbaikalia. } \\
\text { Hamar-Daban ridge }\end{array}$ & $\begin{array}{l}\text { Altai. North- } \\
\text { Chuysky ridge }\end{array}$ \\
\hline \multirow{2}{*}{$\begin{array}{c}\text { Heat supply } \\
\text { conditions }\end{array}$} & \multicolumn{3}{|c|}{ Climate trends } \\
\hline & Thermophilic & Xerophilic & Microthermal \\
\hline \multirow{2}{*}{$\begin{array}{l}\text { The scheme of the } \\
\text { mountain } \\
\text { expositional forest- } \\
\text { steppe }\end{array}$} & \multicolumn{3}{|c|}{ Positions of associations of larch forests in the landscape } \\
\hline & SW & 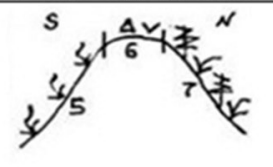 & 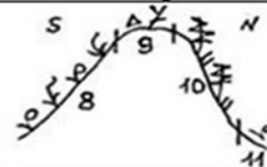 \\
\hline Associations & \multicolumn{3}{|c|}{ Indicator species } \\
\hline $\begin{array}{l}\text { Larch forest with } \\
\text { Lonicera } \\
\text { microphylla and } \\
\text { Artemisia gmelinii }\end{array}$ & $\begin{array}{l}\text { Lonicera microphylla, } \\
\text { Cotoneaster } \\
\text { melanocarpus, } \\
\text { Spiraea hypericifolia, } \\
\text { Artemisia gmelinii }\end{array}$ & & \\
\hline $\begin{array}{l}\text { Larch herbaceous } \\
\text { forest with Carex } \\
\text { pediformis and } \\
\text { Achnatherum } \\
\text { sibiricum }\end{array}$ & & $\begin{array}{l}\text { Achnatherum } \\
\text { sibiricum, Artemisia } \\
\text { comutata, Carex } \\
\text { pediformis, } \\
\text { Helictotrichon } \\
\text { altaicum }\end{array}$ & \\
\hline $\begin{array}{l}\text { Larch herbaceous } \\
\text { forest with Iris } \\
\text { ruthenica and Carex } \\
\text { macroura }\end{array}$ & & & $\begin{array}{l}\text { Spiraea media, } \\
\text { Cotoneaster } \\
\text { melanocarpus, Iris } \\
\text { ruthenica, Carex } \\
\text { macroura, Polygola } \\
\text { hybrida }\end{array}$ \\
\hline
\end{tabular}

Fig. 1. The scheme of assembling relict larch communities in landscapes of the mountain foreststeppe of SS at different time stages of the Cenozoic. Note. Phytocenoses in the schemes of the exposition forest-steppe: 1 - wormwood-fescue steppes; 2 - petrophytic mixed grass steppes; 3 bushes; 4 - honeysuckle-wormwood larch; 5 - junegrass-bluegrass steppes; 6 - stony low grass steppes; 7 - sedge-needlegrass larches with Helictotrichon altaicum; 8 -motley-turfgrass steppes; 9 petrophytic shrubs; 10 - iris-sedge larches; 11 - richly grassy meadow steppes.

The invasion processes also had opposite trends - the introduction of shrubs into forest coenoses, but their role was much less pronounced. This is due to the fact that the dense grass-shrub layer of closed larches gave little chance for the introduction of shrubs under the canopy of the forest community (Fig. 2). In contrast, incumbation phenomena - the introduction of tree layer species into shrub groups developed more intensively, contributing to the formation of distinctive forest communities of the ancient forest-steppe. The formation of great forest-steppe complexes as a result of incumbation (overlapping) of the larch layer on the shrubbery - "Tuvinian shiblyak" with the formation of shrub larches is shown in the diagram.

It is important to note that in the species composition of larches, especially its shrub layer, the role of typical boreal species such as Spiraea media [7], Rosa acicularis, Berberis sibirica, and others was insignificant in comparison with the characteristic elements of the semiarid florocenotypes ("shiblyak", friganoids) of ancient Middle-earth. 


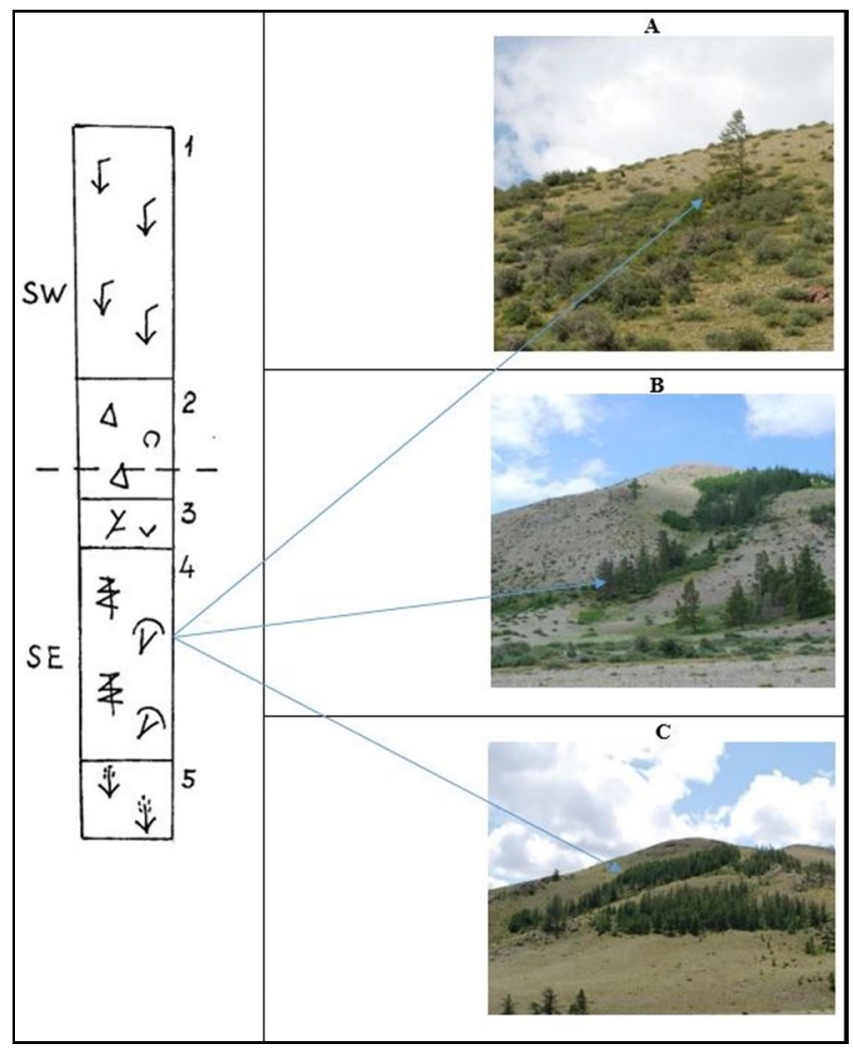

Fig. 2. The scheme of spatial organization of the mountain forest-steppe and the stage of formation of relict larch communities (Western Tannu-Ola ridge, southern macro-slope, Khorlety natural boundary). Note. Slope expositions: SW - southwest; NE - northeastern. ------ - the centerline of the hills. Phytocenoses on the transect: 1 - wormwood-fescue steppes; 2 - petrophytic mixed grass steppes; 3 - bushes; 4 - small-leaved honeysuckle-wormwood larch forest; 5 - motley bluegrass steppes. Stage of formation of relict larch: A - single invasions of larches (ecthesis, according to F. Clements) along the periphery of shrubs; B - Incumbation of the tree layer from Larix sibirica on "shiblyak" communities (thickets of petrophytic xeromorphic shrubs); C - small-leaved honeysucklewormwood larch forest - the result of incumbation.

The species composition of forest phytocenosis is striking in its original combination of elements composed of species of shrubs of the floristic complex of the mountains of Central Asia - Lonicera microphylla, Cotoneasater megalocarpus, Spiraea hypericifolia, Juniperus sabina, Achnatherum sibiricum, Artemisia gmelinii and others [8]. Among them, participation in the shrub layer of the community of small-leaved honeysuckle, an element of the Altai-Dzhungar-Tien Shan relict florocenotype of highland-Asian shrubs, is especially significant phylogenetically [5]. Lonicera microphylla Willd. ex Roem. belongs to the special and most ancient subsection Purpurascentes Rehd. of erect honeysuckle Section Isaka Rehd., formed in the Paleogene, which also includes the original species L. tangutica Maxim., common in Western China - in the Gansu province [8]. The remaining accompanying shrubs species of relict larch forest composed by Cotoneaster megalocarpus Popov, Spiraea hypericifolia L., Juniperus pseudosabina Fisch. \& C.A. Mey., which make up the characteristic florescenocomplex of the vegetation of the Pamir mountain xerophytes, as well as the Dzhungar-Tien Shan "shiblyak". 
In the Quaternary, events developed under the prevailing effect of ice cover, both on the plains and in the mountains, which resulted in cryophilization of natural conditions in the Pleistocene [9]. These phenomena made significant adjustments to the structure of larch communities, and many species genetically associated with the thermophilic flora of the mountainous Central Asia fell out. As a result of cryoaridization, grass polycarpics gain an advantage in ecosystems. In fact, the species from these groups formed the basis of the prevailing synusia both in the steppes and in grassy larch forests.

Unlike Tuvan, the mountain forest-steppe of Transbaikalia, as part of its forest component, has original communities that diagnose the cryoarid stages of its formation, in particular the Pleistocene. This led to the processes of cryomorphogenesis of plant species and communities under periglacial conditions of both mountain glaciers and firn fields, and as a result of the cooling effect of the Baikal ice basin. Adaptive morphogenesis in a cold and moderately humid climate of the initial stages of the Pleistocene for more than 100 thousand years contributed to the development of special types of ecobiomorphs - shortrhizome and rosette and turfy grass polycarps [1]. The formation of the cold periglacial forest-steppe of Transbaikalia with the predominance of hemiboreal herbaceous larch with Helictotrichon altaicum Tzvelev, Festuca sibirica, Carex pediformis - indicators of the Pleistocene cryophytic forest-steppe is associated with these stages of phylocenogenesis. [10].

Periglacial forest-steppe in the understanding of I. M. Krasheninnikov is a landscape with an alternation of steppes, pine and larch forests. In the composition of these steppes, as well as under the canopy of forest communities, the main role was played not by feather grasses, but by helictotrichon and "numerous immigrants from Eastern Siberia and Northern Mongolia." The main focus of the development of cold continental steppes and light coniferous forests of the Pleistocene forest-steppe, he considered the territory between Vilyui in the north and Hangai (Northern Mongolia) in the south. Namely, in the south of Eastern Siberia in the region of the Baikal-Khangai mountain structure, landscape analogues of the Pleistocene forest-steppe have been preserved to date [10]. It is interesting to note that A.V. Kuminova [11] was classified Helictotrichon desertorum (Less.) Nevski (Helictotrichon altaicum in the mountains) as one of the most characteristic species of the forest-steppe genetic group, which is related to the Pleistocene by origin. The participation of the Helictotrichon altaicum in the forest community - sedge-needlegrass larch forest in the expositional forest-steppe of the Selenga Dauria is relict. Thus, in this example, the original coenofloristic complex of grass larch forest with the participation of Helictotrichon altaicum, Festuca sibirica Hack. ex Boiss and substitute Artemisia commutata Besser confirm the originality of the Transbaikal vegetation in the depths of the "ancient crown of Asia", where the mountains belong and Transbaikalia valleys as part of ancient Angarida (Fig. 1).

In the Holocene, with the deglaciation of mountain glaciers and the formation of a relatively warm and temperate Holocene climate (from xerothermic epochs to the present), the stage of the historical formation of the modern mountain forest-steppe under the semihumid climatic regime of the SS is created $[9,10]$.

A plot of the expositional larch forest-steppe in Central Altai was taken as a reference for a typical forest-steppe (Fig. 1). Model phytocenosis - motley-iris-sedge larch forest, which stands out for its rich species composition of herbaceous plants, along with welldeveloped undergrowth from shrubs Spiraea media, Cotoneaster melanocarpus, Rosa acicularis, Lonicera altaica, Caragana arborescens, Dasiphora fruticosa and others [11]. A characteristic feature of a typical forest-steppe is the formation of a fringe, consisting of both shrubs of the forest community and the inclusion of a number of specific mesoxerophytes and xerophytes of the steppe floristic complex, such as Caragana pygmaea, Koeleria cristata, Allium strictum, Veronica incana, Potentilla tanacetifolia, 
Schizonepeta multifida, Scorzonera radiata and others, which gradually through a series of transitional groups, come into contact with the steppe communities of more insolated slopes of the forest-steppe. These are the most important stages in the formation of the larch forest-steppe in the mountains of the SS and the features of forest communities in its structure.

In general, in the larch forests of the forest-steppe belt of Central Altai, the positions of typically taiga species are very weak and, in general, close to the grass forests of the subtaiga zone. Their formation began under the conditions of xerothermic Holocene and continues at present; these are the processes of cryo- and mesoxerophytization of grass and forest communities, the development of floristic complexes of meadow steppes and hemiboreal forests of the mountain forest-steppe from Altai to East Transbaikalia and Amur Region.

\section{References}

1. B. B. Namzalov, The concept of "relict" in geobotany: the history of the issue and modern approaches, in Bulletin of the Samara Scientific Center of the Russian Academy of Sciences, 14, 1799 (2012)

2. I. M. Krasnoborov, About the "tundra steppes" in the south of Siberia, in Vegetation of the highlands, 131 (1986)

3. E. G. Bobrov, History and systematics of larch (Publisher "Nauka", Leningrad, 1972)

4. B. B. Namzalov, Steppes of Tuva and Southeast Altai (Publisher "Geo", Novosibirsk, 2015)

5. R. V. Kamelin, East-ancient Mediterranean mesoxerophilic and xerophilic deciduous forests, light forests and shrubs (shiblyak). Deciduous xerophilous forests, light forests and shrubs, in Proceedings of Botanical Institute named after V. L. Komarova, 17, 26 (1995)

6. V. B. Sochava, Model of a new map of the world's vegetation, in Geobotanical mapping, 3 (1964)

7. Flora of Siberia, 1-13 (Publisher "Nauka", Novosibirsk, 1987-1997)

8. V. P. Goloskokov, Flora of the Dzungarian Alatau: (compendium and analysis) (Publisher "Nauka", Alma-Ata, 1984)

9. A. A. Velichko, Natural process in the Pleistocene (Publisher "Nauka", Moscow, 1973)

10. I. M. Krasheninnikov, The role and importance of the Angarsk floristic center in the phylogenetic development of the main Eurasian wormwood groups of the subgenus Euartemisia, in Materials on the history of flora and vegetation of the USSR, 3, 62 (1958)

11. A. V. Kuminova, Some issues of the formation of the modern Altai vegetation cover, in Materials on the history of flora and vegetation of the USSR, 4, 438 (1963) 